\title{
The effects of diversion of intestinal contents on the progress of Crohn's disease of the large bowel
}

\author{
J. H. BURMAN, H. THOMPSON, W. T. COOKE, AND J. ALEXANDER \\ WILLIAMS \\ From the Nutritional and Intestinal Unit, The General Hospital, Birmingham
}

SUMmaRY This study shows that faecal diversion by ileostomy or colostomy results in an improvement in the patient's general health which is substantiated by the haematological and biochemical findings. However, in the bowel distal to the diversion there is always histological evidence of mucosal and transmural disease and complications such as fistulae may still occur. In only two patients $(7 \%)$ was restoration of bowel continuity successful.

Preliminary reports have suggested that in Crohn's disease of the colon diversion of intestinal contents by defunctioning ileostomy or colostomy would so 'rest' the distal diseased bowel that restoration of the faecal stream might be feasible later (Truelove, Ellis, and Webster, 1965; Oberhelman, Kohatsu, Taylor, and Kivel, 1968). Successful restoration of intestinal continuity was reported recently in three out of $18(16.6 \%)$ patients (Oberhelman, Kohat, Taylor, and Porteous, 1970).

This paper presents a study of 29 patients with Crohn's disease in whom defunctioning ileostomy or colostomy has been performed. These patients have been reviewed in an attempt to evaluate: (1) the clinical improvement after diversion, (2) the degree of resolution of disease activity in the bypassed bowel, and (3) the feasibility and success of restoration of continuity.

\section{Patients}

There were 15 men and 14 women in this study which extended from 1947 to 1969 with a mean follow up of 10 years. All had Crohn's disease of the large bowel diagnosed by barium studies, together with histological evidence.

There was evidence of previous small bowel disease in eight patients and concurrent small bowel disease was observed at operation in seven. In addition, small bowel disease developed subsequently in six patients between eight months and six years after colectomy. Three patients in this series are dead: Received for publication 29 September 1970. one from acute haemorrhagic ileitis five years after pan-proctocolectomy, the second from multiple entero-enteric fistulae one year after colectomy, and the third from small bowel infarction seven years after closure of the colostomy.

\section{Methods}

Indices of general health before and after diversion were taken from historical records. Details of weight and haemoglobin levels (24 patients) were collected, together with values of serum albumin (21 patients) and serum seromucoid (15 patients).

An assessment of disease activity in the defunctioned bowel was sought from the subsequent course of events in each case either from sigmoidoscopy and biopsy or from histological examination after later excision. At sigmoidoscopy mucosal ulceration and friability with contact bleeding were taken to be criteria of continued activity of the disease. Histologically evidence of continued activity was inferred from the presence of an inflammatory cellular infiltrate, mucosal ulceration, submucosal oedema and fibrosis, or the presence of giant cells. Finally, the presence and progress of perianal disease was observed.

\section{Results}

THE EFFECT OF DIVERSION ON THE GENERAL HEALTH OF THE PATIENT

Following diversion, all but one patient showed improvement in general health. This patient became 
acutely depressed. Of the 18 patients with accurate weight records, 15 gained weight, two lost weight, and one remained the same. In those patients where records were available, haemoglobin values rose in every case but one (Fig. 1) and serum albumin levels rose in all but three cases (Fig. 2). An anticipated fall in serum seromucoid levels took place in every case but one; in only six patients, however, did the values fall to the normal level (Fig. 3). Figures 1, 2, and 3 show the average of the values found up to two months before diversion and up to 12 months after diversion in each patient. The Figures show patients subdivided into those in whom some bowel resection was undertaken at the time of diversion and those in whom only diversion was performed. Although the improvement observed was usually greater if some diseased bowel was also resected, there is no significant difference between the two subgroups.

\section{PERIANAL DISEASE}

Perianal disease was observed in 10 patients before diversion. Two patients had a fissure in ano, seven had a fistula in ano, and one man had both. After diversion, over a mean follow-up period of 25 months, all the fissures healed as did one fistula. However, in six patients the fistula in ano did not heal. Three patients developed rectal stricture and in one (case 11, Table I) this was the main indication for the subsequent proctectomy. Furthermore, four patients who had initially not been observed to have perianal disease developed a fistula in ano after diversion. Careful inquiry into the history before diversion revealed no evidence of these patients having previously had perianal disease.

\section{THE EFFECT OF DIVERSION ON THE DISEASE} ACTIVITY OF THE BYPASSED BOWEL

The defunctioned bowel was later excised from 15 patients after an interval of between two and 105 months (mean 37 months) after the diversion operation. The indications for this subsequent resection, together with the operative and pathological descriptions of the bowel removed, are shown in Table I. In none of the excised specimens was the defunctioned bowel normal. Table II shows the percentage frequency with which certain histological features were noted in these 15 cases before and after diversion. While it will be appreciated that these figures are a crude measurement, nonetheless they confirm the macroscopic impression that the defunctioned bowel had not returned to normal. A survey was then made of eight of the patients in whom the rectal remnant is still retained. Table III shows the proportionate frequency with which sigmoidoscopic and biopsy abnormalities were

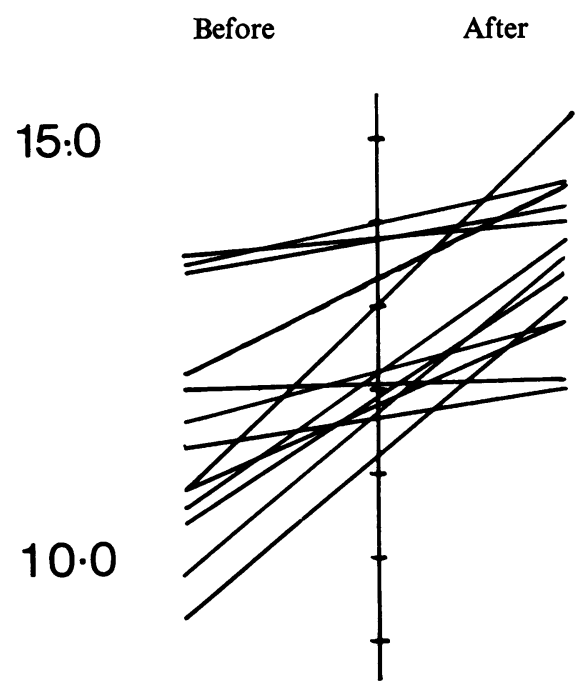

a

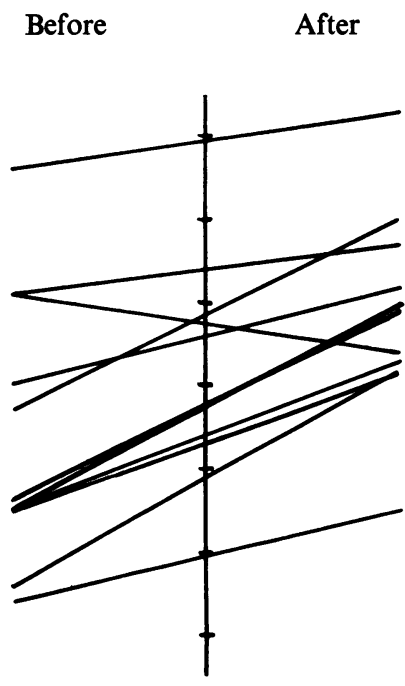

b

Fig. 1. Mean haemoglobin levels in $\mathrm{g}$ per $100 \mathrm{ml}$ in patients before and after diversion of the faecal stream (a) when part or all of the diseased colon was excised at the time of diversion and (b) when no resection was performed. 
The effects of diversion of intestinal contents on the progress of Crohn's disease of the large bowel

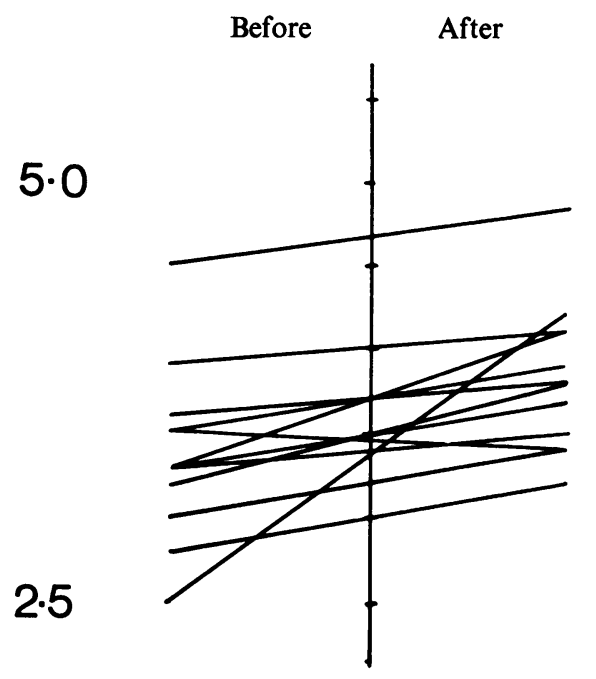

a

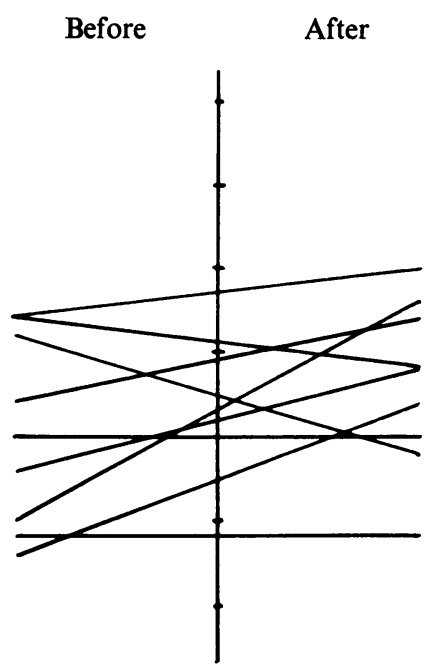

b

Fig. 2. Mean serum albumin levels in $\mathrm{g}$ per $100 \mathrm{ml}$ before and after diversion of the faecal stream (a) when part or all of the diseased colon was excised at the time of diversion and (b) when no resection was performed.

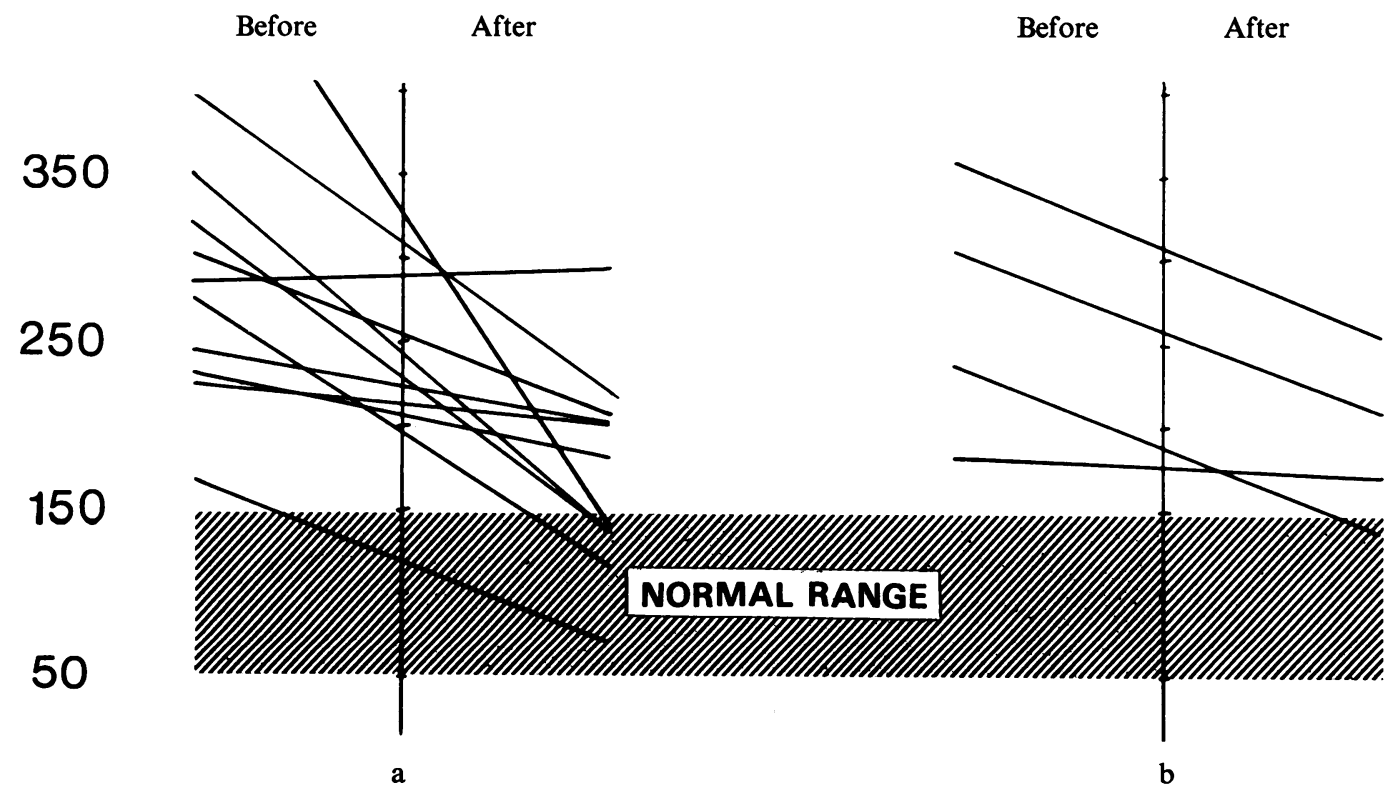

Fig. 3. Serum seromucoid levels in $\mathrm{mg}$ per $100 \mathrm{ml}$ in patients before and after diversion of the faecal stream (a) when part or all of the diseased colon was excised at the time of diversion and (b) when no resection was performed. 


\begin{tabular}{|c|c|c|c|}
\hline Patient & $\begin{array}{l}\text { Time between Defunction } \\
\text { and Later Resection (mth) }\end{array}$ & Reasons for Later Resection & $\begin{array}{l}\text { Macroscopic Description of Defunctioned Bowel } \\
\text { at Time of Resection }\end{array}$ \\
\hline $\begin{array}{l}1 \\
2\end{array}$ & $\begin{array}{r}94 \\
7\end{array}$ & $\begin{array}{l}\text { Anal stenosis, loss of blood and pus per rectum } \\
\text { Persistent anal and perianal sepsis, recto- } \\
\text { vaginal fistula }\end{array}$ & $\begin{array}{l}\text { Thick, contracted colon } \\
\text { Moderate serosal inflammation, mucosal rugosity } \\
\text { and linear ulceration, slight rectal pseudopolyposis }\end{array}$ \\
\hline 3 & 47 & $\begin{array}{l}\text { Sigmoid colon originally involved in ileocolic } \\
\text { fistula. After first stage disconnexion of fistula } \\
\text { sigmoid became strictured. Sigmoidoplasty } \\
\text { failed }\end{array}$ & $\begin{array}{l}\text { Externally normal except for stenosed sigmoid, } \\
\text { loss of mucosal pattern at proximal end of } \\
\text { specimen with fibrosis and superficial ulceration in } \\
\text { rectosigmoid region }\end{array}$ \\
\hline 4 & 22 & Developed fistula in ano and rectal stenosis & $\begin{array}{l}\text { Thickening and scarring of colon, mucosal rugosity } \\
\text { and irregular congestion of rectal mucosa }\end{array}$ \\
\hline 5 & 75 & $\begin{array}{l}\text { Continued discharge of pus from rectum. } \\
\text { Barium enema showed a narrow indistensible } \\
\text { haustral colon, Sigmoidoscopy showed granular } \\
\text { oedematous mucosa with purulent exudate } \\
\text { (thought to be ulcerative colitis with associated } \\
\text { risk of carcinoma) }\end{array}$ & Thickened bowel wall \\
\hline 6 & 105 & $\begin{array}{l}\text { Loss of pus and blood per rectum (thought } \\
\text { to be ulcerative colitis) }\end{array}$ & Thickened sigmoid colon adherent in pelvis \\
\hline 7 & 47 & $\begin{array}{l}\text { Loss of pus and blood per rectum, palpable } \\
\text { pelvic mass }\end{array}$ & $\begin{array}{l}\text { Thickened adherent sigmoid colon with thickened } \\
\text { mesentery }\end{array}$ \\
\hline 8 & 11 & Failure of perianal lesions to subside & $\begin{array}{l}\text { Colon small and short, ulcerated mucosa through- } \\
\text { out colon }\end{array}$ \\
\hline 9 & 26 & $\begin{array}{l}\text { Continuing perianal sepsis, loss of pus and } \\
\text { blood from rectum }\end{array}$ & $\begin{array}{l}\text { Thickened colon with widespread mucosal } \\
\text { ulceration }\end{array}$ \\
\hline 10 & 30 & Fistula in ano, anal stricture & Sigmoid fixed in pelvis at old abscess site \\
\hline 11 & 38 & $\begin{array}{l}\text { Continued perianal disease, rectal stenosis and } \\
\text { purulent rectal discharge (thought to be } \\
\text { ulcerative colitis) }\end{array}$ & $\begin{array}{l}\text { Thickened mesentery and glands, thickened colon } \\
\text { with loss of haustration, widespread mucosal } \\
\text { ulceration }\end{array}$ \\
\hline 12 & 2 & $\begin{array}{l}\text { Following restoration of faecal stream severe } \\
\text { exacerbation of rectal disease and development } \\
\text { of fistula at the old colostomy site }\end{array}$ & $\begin{array}{l}\text { Defunctioning ileostomy performed, no colon } \\
\text { pathology obtained }\end{array}$ \\
\hline 13 & 17 & $\begin{array}{l}\text { Recurrence of Crohn's disease around the } \\
\text { ileorectal anastomosis site after restoration of } \\
\text { faecal stream }\end{array}$ & $\begin{array}{l}\text { Grossly thickened mesentery and lymph nodes, } \\
\text { thickened oedematous colon and ileum, gross } \\
\text { mucosal ulceration }\end{array}$ \\
\hline 14 & 5 & $\begin{array}{l}\text { Severe recurrence of rectal disease two months } \\
\text { after restoration of faecal stream. Purulent } \\
\text { rectal discharge }\end{array}$ & $\begin{array}{l}\text { Perirectal abscess, colon wall thickened, mucosa } \\
\text { cobblestoned with pseudo polypi and ulceration }\end{array}$ \\
\hline 15 & 24 & $\begin{array}{l}\text { Rectal and mucous fistula; discharge of pus and } \\
\text { blood persisted. Sigmoidoscopy and rectal } \\
\text { biopsy showed active disease. Multiple peri- } \\
\text { anal fistulae developed after diversion. }\end{array}$ & $\begin{array}{l}\text { Thickened contracted colon, sigmoid fixed in } \\
\text { pelvis, mucosa ulcerated throughout }\end{array}$ \\
\hline
\end{tabular}

Table I Rationale for the later resection and appearances of the defunctioned large bowel

\begin{tabular}{lll}
\hline Abnormality & \multicolumn{2}{l}{ Incidence (\%) } \\
\cline { 2 - 3 } & At Diversion & At Resection \\
\hline Macroscopic & 100 & 53 \\
Mucosal ulceration & 40 & 13 \\
Linear ulceration & 40 & 13 \\
Cobblestone mucosa & 70 & 73 \\
Bowel wall thickening & & \\
Histological & & \\
Chronic inflammatory cellular & 80 & 53 \\
infiltration & 70 & 47 \\
Submucosal oedema and fibrosis & 40 & 40 \\
Crypt abscesses & 40 & 20 \\
Epithelial cell follicles & 90 & 40 \\
Giant cells & 50 & 27 \\
Lymph node hyperplasia & \\
\hline
\end{tabular}

Table II Incidence of abnormalities in 15 patients found in the colon at the diversion operation and subsequently at the resection

noted before and after diversion. Although there is an overall improvement after diversion, in none of these patients were the findings entirely normal in the rested bowel.
THE FATE OF DIVERTED BOWEL WHEN RETURNED TO CONTINUITY

Five patients have had the bowel continuity restored (from between eight weeks and 33 months after diversion). Two are well with no symptoms. Of the remaining three, one underwent proctectomy three months later because of severe recurrent proctitis,

\begin{tabular}{lll}
\hline Findings & \multicolumn{2}{l}{ No. of Patients } \\
\cline { 2 - 3 } & Before Diversion & After Diversion \\
\hline Sigmoidscopic & & 4 \\
Rectal stricture & 1 & 7 \\
Mucosal ulceration & 5 & \\
Mucosal biopsy & & \\
Chronic inflammatory cellular & & 5 \\
infiltration & 6 & 1 \\
Submucosal oedema and fibrosis & 5 & 1 \\
Giant cells & 2 & \\
\hline
\end{tabular}

Table III Sigmoidoscopy and biopsy findings before and after diversion in eight patients still retaining defunctioned bowel

${ }^{1}$ Mean period since diversion 25 months 
a second required an emergency loop ileostomy two months after because of diarrhoea and the development of a colocutaneous fistulae, and the third suffered ill health for seven years, developing fistulae both entero-cutaneous and entero-vesical, and eventually died of mesenteric infarction. In the two successful cases recent sigmoidoscopy and biopsy revealed a friable mucosa with histological evidence of a chronic inflammatory reaction.

NEOPLASIA

Neoplasia has not been observed in any patient in this survey.

\section{Discussion}

In all our patients diversion of the faecal stream away from an area of active colitis has had a beneficial effect upon the patient. Their general health has improved and this has been borne out by the haematological and biochemical evidence. The fact that similar improvement occurs whether or not the diseased colon is resected suggests that it is due to the fact that faeces are no longer passing over the diseased bowel.

In only two patients has restoration of the faecal stream been successful, and in none have the histological findings at biopsy returned to normal. While it can be argued that slight mucosal ulceration and chronic inflammatory reaction are non-specific changes and that these patients can be controlled by medical means after restoration of faecal flow, we have only found this to be practicable in two $(7 \%)$ in our series. Perianal disease has developed de novo in four patients after diversion and rectal stricture in three others. As a result of our experience we feel that there is only a small chance that 'resting' the large bowel will lead to healing in Crohn's colitis sufficient to allow restoration of the faecal stream.

Requests for reprints to J.A.W., The General Hospital, Birmingham, B4 $6 \mathrm{NH}$.

\section{References}

Oberhelman, H. A., Jr., Kohatsu, S., Taylor, K. B., and Kivel, R. M. (1968). Diverting ileostomy in the surgical management of Crohn's disease of the colon. Amer. J. Surg., 115, 231-240.

Oberhelman, H. A., Jr., Kohatsu, S., Taylor, K. B., and Porteous, J. (1970). Diverting ileostomy for Crohn's disease of the colon. 4th World Congress of Gastroenterology, Copenhagen. Abstracts, p. 231.

Truelove, S. C., Ellis, H., and Webster, C. D. (1965). The place of a double-barrelled ileostomy in ulcerative colitis and Crohn's disease of the colon: A preliminary report. Brit. med.J., 1, 150-153. 